\title{
THE IMPACT OF ATTRACTIVENESS OF ADS AND CUSTOMER COMMENTS AGAINST TO PURCHASE DECISION OF CUSTOMER PRODUCTS ON THE USER OF ONLINE SHOP APPLICATIONS IN THE CITY OF MEDAN
}

\author{
Muhammad Agung Anggoro', Mas Intan Purba' \\ Department of Management, Universitas Prima Indonesia \\ muhammadagunganggoro@unprimdn.ac.id ${ }^{1}$, \\ masintanpurba84@gmail.com²
}

\begin{abstract}
The increasingly fierce competition of online shop products spurred online shop application providers to undertake business development strategy steps by strengthening digital business services and various service innovations to meet customer needs. This can be seen from the public interest in shopping at online stores because prices are more competitive, there is no need to bother coming directly to the store, and the goods purchased will be delivered to the buyers' place. The population in this study that used mobile shop online application services was 105,551 respondents with the formula Slovin obtained a sample size of 100 respondents. The research data analysis method is quantitative descriptive statistical analysis and multiple regression analysis. The result of this research is that the attractiveness of advertisements and customer comments together have a positive and significant effect in increasing customer product purchasing decisions for users of online shop applications in Medan, while partially the attractiveness of advertising (X1) only has a positive and significant effect, but the variables customer comments (X2) have no positive effect in improving customer product purchasing decisions on users of online shop applications in the city of Medan.
\end{abstract}

Keywords : Attractiveness of Ads, Customer Comments, Purchase Decision

Abstrak : Persaingan produk online shop yang semakin ketat memacu perusahaan penyedia aplikasi online shop untuk melakukan langkah strategi pengembangan usaha dengan perkuatan layanan bisnis digital serta beragam inovasi layanan untuk memenuhi kebutuhan pelanggan. Hal tersebut terlihat dari ketertarikan masyarakat berbelanja di toko online dikarenakan harga yang lebih kompetitif, tidak perlu ribet datang langsung ke toko, dan barang yang dibeli akan diantar ke tempat pembeli. Populasi dalam penelitian ini yang menggunakan layanan mobile aplikasi online shop sebanyak 105.551 responden dengan rumus slovin diperoleh jumlah sampel sebanyak 100 responden. Metode analisis data penelitian adalah analisis statistik deskriptif kuantitatif dan analisis regresi berganda. Hasil penelitian diperoleh daya tarik iklan dan komentar pelanggan secara bersama-sama berpengaruh positif dan signifikan dalam meningkatkan keputusan pembelian produk pelanggan pada pengguna aplikasi online shop di Kota Medan, sedangkan secara parsial variabel daya tarik iklan (X1) saja yang berpengaruh positif dan signifikan tetapi variabel komentar pelanggan (X2) tidak berpengaruh positif dalam meningkatkan keputusan pembelian produk pelanggan pada pengguna aplikasi online shop di Kota Medan.

Kata Kunci : Daya Tarik Iklan, Komentar Pelanggan, Keputusan Pembelian 


\section{INTRODUCTION}

The development of an online shop through internet media has mushroomed in Indonesia, even it is very well known by the general public. The many diverse conveniences in shopping and various types of products and services offered, making the Indonesian people make the online shop as one of the "shopping places" in addition to shopping centers. This makes many online shop sellers competing to offer their products in various ways to attract consumers to shop, they take advantage of a situation where Online Shopping is currently in demand by the people of Indonesia to date. Online shopping sites are often referred to as e-commerce sites, which is a process of buying and selling products electronically by consumers and from company to company with computers as business transactions. This is what makes customers more interested in shopping online in addition to a large selection of products that also have better ad appeal than other online shops. The attractiveness of advertising through internet media was quite effective, evidenced by the results of a survey of the Indonesian Internet Service Providers Association (APJII) that out of a total of 143.26 million internet users in 2017 (54.68\% of the total population of Indonesia), around 135 million did online shopping. Attraction can be divided into two categories namely rational appeal and emotional attraction. A rational appeal in advertising is the appeal of advertising that focuses on the functional needs, usability, or usefulness of a product and focuses on the products and benefits obtained when using the product. Furthermore, emotional appeal in advertising is an attraction that is related to social and psychological needs so that consumers are motivated to buy the advertised product. On the other hand, the buyers' comments on the products that have been purchased will post their satisfaction with the online shop product. This is certainly expected to have an impact on the judgment of other buyers to decide whether or not to buy the product from the service provider. Positive comments will also give a positive assessment of the products to be offered, for example from online shop service providers Lazada posted advertisements of electronic products to be offered but received a negative response from other buyers due to the mismatch of product quality expected after making a purchase and the comments were seen by other buyers. will affect his desire to make a purchase of the product offered. Therefore, online shop application providers must evaluate the input and comments from customers so as not to affect other customers. The scope of the study focuses on increasing customer product purchasing decisions on users of online shop applications in the city of Medan because the impact of the attractiveness of advertisements and customer comments is one of the ratings for buying a product. The formulation of the problem of this research is how the influence of the attractiveness of advertisements and customer comments 
in improving customer product purchasing decisions on users of online shop applications in the city of Medan. The purpose of this study is to examine and analyze the effect of advertisement attractiveness and customer comments on improving customer product purchasing decisions on online shop application users in Medan. The benefits of research that can be obtained from this research are to facilitate the public in obtaining information about the advantages of online shop applications and to facilitate customer products that can be sold on online applications.

\section{LITERATURE REVIEW}

\section{Attractiveness of Ads}

Kotler and Armstrong (2008) say ad makers must think of an attraction because according to them the appeal of advertising can affect the effectiveness of advertising. An attractive ad is an ad that has an appeal, which has the ability to attract the attention of the target market (audience). The messages to be conveyed can be presented in different delivery styles, namely by displaying: footage of individual or group lives, individual lifestyles, fantasies about the product, moods or images around the product, music to bring more messages, symbols personality to create characters that personify products, showcase the expertise and experience of companies in producing products, scientific evidence of product superiority, evidence or testimony from famous people (Tjiptono, 2008). Suharno and
Sutarso (2010) say there are 3 (three) types of attractiveness, namely rational appeal related to the self-interest of the public. The appeal shows that the product will produce the desired benefits. (1). The emotional attraction that evokes emotions both negative and positive that can motivate purchase. (2). The moral appeal is directed at the audience's "feelings" about what is "right" and "appropriate". This attraction is often used to encourage people to care and do charity for social activities. The rational appeal related to the self-interest of the audience. The appeal shows that the product will produce the desired benefits. (3). An emotional attraction that evokes emotions both negative and positive that can motivate purchase. Communicators may use positive attractions such as love, pride, pleasure, and humor. It can also use negative attractions such as fear, guilt, and shame that invite people to do things they should do or stop doing things they should not do. The moral appeal is directed at the audience's "feelings" about what is "right" and "appropriate". This attraction is often used to encourage people to care and do charity for social activities.

\section{Customer Comments}

Ahmadi (2009: 68) says the response as one of the main souls can be interpreted as a picture of memory from observation, when the object that has been observed is no longer in the space and time of observation. So, if the observation process has stopped, and 
only the impressions are left, such an event is called a response. Responses are called "latent" (hidden, not yet revealed), if the response is subconscious, or we are not aware of it. While the response is called "actual" (actual $=$ really) if we realize the response. (Ahmadi, 2009: 68). Suryabrata (2011: 36) says responses are shadows that remain in memory after we make observations. From some of the explanations above, we can know that the indicators of that response are happy or positive and not happy or negative. Regarding this displeasure with each person is different.

\section{Purchase Decision}

Kotler (2009) says the buying decision is: "Several stages carried out by consumers before making a purchase decision on a product". Setiadi (2010) says buying behavior implies that individual activities are directly involved in exchanging money for goods and services and in the decisionmaking process that determines these activities. Consumer decisions to buy a product always involve physical activity (in the form of direct activities of consumers through the stages of the decision making the process of purchase) and mental activities (ie when consumers assess the product according with certain criteria set by individuals). Hsu and Chang (2008) say suggested indicators measure purchasing decisions as follows, namely (1) The desire to use the product. (2) The desire to buy products. (3) Prioritizing the purchase of a product. (4). Willingness to sacrifice (time, cost and energy) to get a product. Sweeney (2008) says states that the purchase decision indicator is to buy or not buy associated with confidence in buying and would not expect any problem, namely the hope not to get into trouble or risk, and consideration for getting benefits from the product. Based on the above description, the buyer's decision indicators used in this research are as follows: (1) Buying decision. (2) The decision not to buy.

\section{CONCEPTUAL FRAMEWORK}

The attractiveness of advertising is one of the customer ratings, especially in increasing product sales. This is supported by the product's ability to provide value to perceptions or ratings in the form of comments given by customers relating to the performance of the product. Therefore for customer comments on the online shop application service, either positively or negatively will affect the buyer's judgment to make a purchase of the advertised product. Purchase decisions also occur if the online shop product ads get a lot of positive comments compared to negative comments and in these comments, customers also suggest to buy products online shop because the product does not disappoint and in accordance with the appearance of the products in the service advertisement. Therefore this research is expected to provide input to online shop application services to provide the best service and this can support MSME owners to market their products by using online 
shop application services in Indonesia. Based on the explanation above, it can be made systematically the relationship between the impact of the attractiveness of advertising and customer comments on customer product purchasing decisions on online shop application users in Medan city with the framework in Figure 1 below:

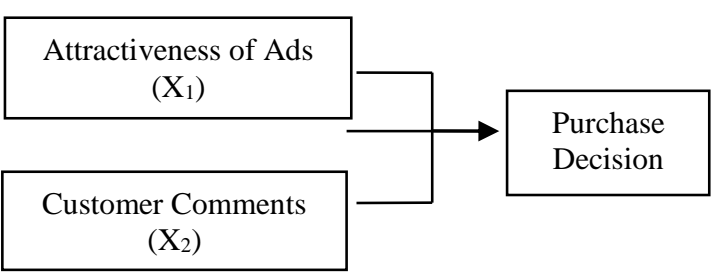

Figure 1. Conceptual Framework

\section{Population and Sample}

The location of the study was conducted in the Medan City area. The approach used in this study is a survey approach. This type of research is a quantitative descriptive study. The nature of the research is explanatory research. The population in this study is the number of users of online application services using online shop application mobile services such as Lazada.co.id,Blibli.com,

Tokopedia.com, Elevania.co.id, Matahari Mall.com, Shopee.co.id, Bukalapak. com, Zalora.co.id, Qoo10.co.id, Blanja.com.

Table 1.

Online Shop Application Service Users

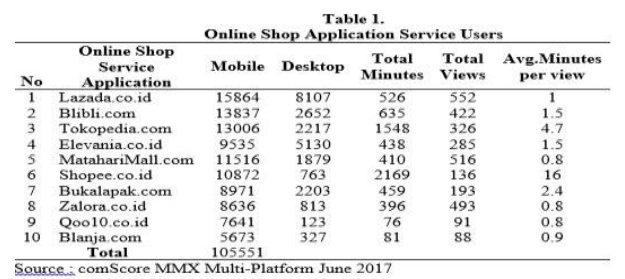

Sampling using a non-probability approach. The type of sampling chosen was accidental sampling with the type of qualified volunteer sample. The sample determination technique used in this study was using the Slovin formula so that obtained a total sample are 100 respondents

$n=\frac{N}{1+N(e)^{2}}=\frac{105551}{1+105551(0,1)^{2}}=\frac{105551}{1056.51}=99,90 \approx 100$

Where :

$\mathrm{n}=$ sample size

$\mathrm{N}=$ population size

$\mathrm{e}=$ percentage error $(10 \%)$

\section{Variable Identification and Operations}

Identification and operation there are dependent variables Purchase Decisions (Y), independent variables consisting of Attractiveness of Ads (X1), Customer Comments (X2).

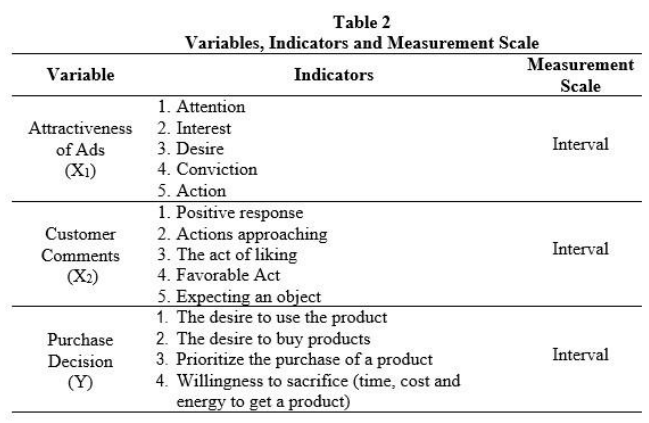

\section{Research Methods}

The statistical analysis used in this study uses statistical analysis with multiple linear regression analysis. This analysis is to determine the direction of the relationship between the independent variable with the dependent variable whether each independent variable is positively or negatively 
related and to predict the value of the dependent variable if the value of the independent variable has increased or decreased (Ghozali, 2013). This research model is described based on the regression equation. The regression equation is multiple regression to test all hypotheses in the study, including:

\section{Hypothesis $1\left(\mathrm{H}_{1}\right)$}

Effect of Attractiveness Advertisements $\left(\mathrm{X}_{1}\right)$ on Purchasing Decisions $(\mathrm{Y})$ $\mathrm{Y}=\mathrm{a}+\mathrm{b}_{1} \mathrm{X}_{1}+\mathrm{e}$

\section{Hypothesis $2\left(\mathbf{H}_{2}\right)$}

Effect of Customer Comments $\left(\mathrm{X}_{2}\right)$ on

Purchasing Decisions (Y)

$\mathrm{Y}=\mathrm{a}+\mathrm{b}_{2} \mathrm{X}_{2}+\mathrm{e}$

\section{Hypothesis $3\left(\mathrm{H}_{3}\right)$}

Effect of Attractiveness of Advertising $\left(\mathrm{X}_{1}\right)$ and Customer Comments $\left(\mathrm{X}_{2}\right)$ together on Purchasing Decisions (Y).

\section{$Y=a+b_{1} X_{1}+b_{2} X_{2}+e$ \\ Information :}

a $\quad=$ constant

b1, b2 = Regression Coefficient of

Each Variable

$\mathrm{X} 1=$ Attractiveness of Ads

$\mathrm{X} 2=$ Customer Comments

$\mathrm{Y}=$ Purchase Decision

$\mathrm{e} \quad=$ error

According to Siregar (2014: 405), the data analysis model in this study is multiple regression analysis where the application of multiple regression methods uses the number of independent variables used more than one that affects one dependent variable.
The results of the research analysis model tests can be seen in Table 3 below:

\begin{tabular}{|c|c|c|c|c|c|c|}
\hline Coef & Res & $\operatorname{arch} A$ & $\begin{array}{l}\text { Table } 3 \\
\text { lysis Model T }\end{array}$ & Results & & \\
\hline & Model & & ndardized & Standardized & $\mathrm{t}$ & Sig. \\
\hline & & & fficients & Coefficients & & \\
\hline & & B & Std. Error & Beta & & \\
\hline & (Constant) & 6.645 & 1.620 & & 4.102 & .000 \\
\hline 1 & $\begin{array}{l}\text { Attractiveness of Ads } \\
\text { (X1) }\end{array}$ & .136 & .087 & .163 & 1.561 & .122 \\
\hline & $\begin{array}{l}\text { Customer Comments } \\
\text { (X2) }\end{array}$ & .107 & .102 & .109 & 1.047 & .298 \\
\hline
\end{tabular}

Based on Table 3 above we get the multiple linear regression equation, which is as follows:

$Y=6.645+0,136 X_{1}+0,107 X_{2}+e$

The regression equation model above can be interpreted that a constant of 6.645 has the meaning that if the value of the independent variable that is ad appeal and customer comment is zero is considered non-existent then the purchase decision is at $6,645 \%$. The attractiveness of advertising $\left(\mathrm{X}_{1}\right)$ has a regression coefficient of 0.136 , that means that each increase of one percent of the attractiveness of advertising will give an increase in customer product purchasing decisions of 0.136 or $13.6 \%$ if other variables are assumed to be constant. This provides an explanation that the attractiveness of advertising is a part whose change is in line with the increase in purchasing decisions. Customer comment $\left(\mathrm{X}_{2}\right)$ has aregression coefficient of 0.107 , that means that every 1 percent increase in customer comment variables will give an increase in customer product purchasing decisions increase of 0.107 or $10.7 \%$ if other variables are assumed to be 
constant. This provides an explanation that customer comments are part of the changes in the direction of increasing customer product purchasing decisions.

\section{Discussion}

1. Partial testing (t-test) conducted on hypotheses 1 and 2 is to test partially the independent variables consisting of the attractiveness of advertising (X1) has a positive and significant influence in increasing customer product purchasing decisions on users of online shop applications in Medan, while customer comments (X2) do not have a significant positive effect in improving customer product purchasing decisions on users of online shop applications in the city of Medan.

Table 4.

t-test results

\begin{tabular}{llcr}
\hline Model & & $\mathrm{t}$ & Sig. \\
\hline & (Constant) & 4.102 & 0 \\
& Attractiveness of & & 0.1 \\
& Ads (X1) & 1.561 & 22 \\
& Customer & & 0.2 \\
& Comments (X2) & 1.047 & 98 \\
\hline
\end{tabular}

a. Dependent Variable: Purchase Decision

Source : Primary Data Processed 2019

Based on Table 4 above, it appears that:

- Partial hypothesis testing variable attractiveness of advertisements from the table can be seen t-value of the variable attractiveness of advertisements (X1) amounted to 1.561 with a significance of 0.122 . So the results of the study show the hypothesis $\mathrm{H} 1$ is accepted because $\mathrm{t}$ count > t-table $(1.561>1.290)$ and significantly greater than 0.10 which means that the attractiveness variable of advertising (X1) has a positive and significant effect in increasing customer product purchasing decisions on users of online shop applications in Medan city.

- The partial hypothesis test of the customer comment variable from the table can be seen the t-count of the customer comment variable (X2) is 1.047 with a significance of 0.298 . Then the results of the research show the hypothesis $\mathrm{H} 1$ is rejected because t-count < t-table $(1.047<1.290)$ and the significance is greater than 0.10 which means that the customer comment variable (X2) does not affect in increasing customer product purchasing decisions on users of online shop applications in Medan City.

Based on the significance of the variable attractiveness of advertisements and customer comments, it can be seen that the most dominant factor influencing the increase in customer product purchasing decisions in online shop application users in Medan is the customer comment variable (X2).

2. Simultaneous testing (Test F) in hypothesis 3 is to see together the influence or positive and significant relationship of independent variables $(\mathrm{X} 1, \mathrm{X} 2)$ in the form of advertising attractiveness variables and customer comments on the 
dependent variable (Y) in the form of variables in product purchase decisions customers in the online shop application users in the city of Medan.

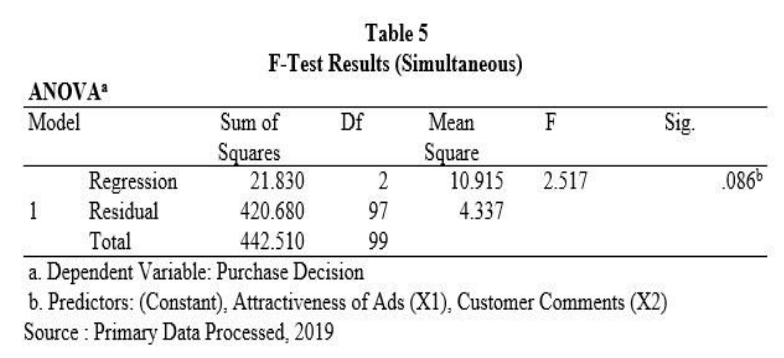

Simultaneous testing or F test aims to see how the influence of digital marketing and easy access to services in improving the purchasing power of the Medan city community in the era of the marketing industry revolution 4.0. Based on the test results above, the Fcount value of 2,517 and a significance value of 0.086 are obtained. The Fcount value will be compared with the Ftabel value of 2.36 (obtained by looking at the Ftabel with the criteria df $1=2$ and df $2=$ greater than 97), the results obtained are F-count $>$ F-table $(2.517>2.36)$ and a significance value of $0.086<0.10$ so that it can be concluded that the attractiveness of advertising and customer comments together have a positive and significant effect on customer product purchasing decisions on users of online shop applications in the city of Medan.

\section{Conclusions and Suggestions}

From the results of the study, it can be concluded that:

1. The attractiveness of advertising greatly influences customers' buying decisions in making purchases using online shop services such as Lazada.co.id, Blibli.com, Tokopedia.com, Elevania.co.id, Matahari Mall.com, Shopee.co.id, Bukalapak.com, Zalora.co.id, Qoo10.co.id, Blanja.com. Each service provider will provide advertisements as attractive as possible to deliver and offer products to application service users. Promoted advertisements also from service providers have their respective advantages to influence customer purchasing decisions because good ads are not deceptive and match the content delivered through these advertisements.

2. Customer comments do not affect customer purchasing decisions because customer comments are positive and negative. Some negative comments from customers are intentionally given to drop customers' products, but there are also those who give negative ratings because the incompatibility of the products obtained does not match the appearance of the product in the application service advertisement and that is what the customer assesses for online shopping service application users to decide not to make a purchase.

3. Online shopping application service providers must pay attention to customer needs and enter customers with the aim to improve application services and provide a positive assessment that advertising is not just a promotional medium but makes learning media and understanding 
that with online shopping application service customers can easily make purchases and also can sell its products by working with these online shop service providers.

\section{REFERENCES}

\section{Book}

Abu, Ahmadi. (2009). Psikologi Umum. Jakarta; Rieka Cipta.

Chih-Jen Lin, Chih-Wei Hsu, ChihChung, Chang. (2008). A Practical Guide To Support Vector.

Ghozali, Imam, (2013). Aplikasi Analisis Multivariate dengan Program SPSS, Universitas Diponegoro

Kotler, Philip dan Armstrong (2008). Prinsip-prinsip Pemasaran. Edisi 12. Jilid 1. Jakarta; Erlangga

Kotler, Philip. (2009). Manajemen Pemasaran, Edisi 13. Jakarta; Erlangga

Setiadi, Nugroho J. (2010). Perilaku Konsumen. Cetakan 4. Edisi Revisi. Jakarta : Kencana

Sugiyono, 2011, Metode Penelitian, Kombinasi Mixed Methods, Alfabeta, Bandung

Suharno \& Yudi Sutarso, (2010). Marketing In Practice, Graha Ilmu, Yogyakarta

Suryabrata, Sumadi, (2011). Psikologi Pendidikan, Jakarta: PT. Raja Grafindo Persada
Tjiptono, Fandy, (2008), Strategi Pemasaran, Edisi 3, ANDI: Yogyakarta

\section{Journal}

Hariyana, Nanik. (2013). Pengaruh Penggunaan Iklan Endorser Produk Sabun LUX Media Televisi Terhadap Keputusan Pembelian dan Loyalitas Merek Pada Konsumen Produk Sabun LUX di Kabupaten Jember. JEAM. Vol.XII. No.1

Jacob, Aprilia A, Joyce Lapian \& Yunita Mandagie, (2018). Pengaruh Daya Tarik Iklan dan Citra Produk Terhadap Keputusan Pembelian Produk Chitato Chips Pada Mahasiswa FEB UNSRAT. Jurnal EMBA.Vol.6.No.2. Hal $988-997$

Susetyarsi. (2014). Analisis Daya Tarik Sumber Iklan dan Pengaruhnya Terhadap Minat Beli Konsumen Pada Produk Minuman Suplemen Merek Kuku Bima Ener-G!Di Kota Semarang. Jurnal STIE Semarang, Vol 6, No.3.

Sweeney, J. C.(2008). Cognitive Dissonance After Purchase: A Multidimensional Scale. Journal of Psychology \& Marketing

\section{Website}

https://www.investopedia.com/terms/c/c onsumer-goods.asp 